\title{
Penicillium simile sp. nov. revealed by morphological and phylogenetic analysis
}

Correspondence

Domenico Davolos d.davolos@inail.it

\section{Domenico Davolos, ${ }^{1}$ Biancamaria Pietrangeli, ${ }^{1}$ Anna Maria Persiani ${ }^{2}$ and Oriana Maggi ${ }^{2}$}

\author{
${ }^{1}$ Department of Productive Plants and Interaction with the Environment (DIPIA), National Institute of \\ Occupational Safety and Prevention (exISPESL-INAIL), Via Urbana, 167 - 00184 Rome, Italy \\ ${ }^{2}$ Department of Environmental Biology, Sapienza University of Rome, P.le A. Moro, 5 - 00185 \\ Rome, Italy
}

\begin{abstract}
The morphology of three phenetically identical Penicillium isolates, collected from the bioaerosol in a restoration laboratory in Italy, displayed macro- and microscopic characteristics that were similar though not completely ascribable to Penicillium raistrickii. For this reason, a phylogenetic approach based on DNA sequencing analysis was performed to establish both the taxonomic status and the evolutionary relationships of these three peculiar isolates in relation to previously described species of the genus Penicillium. We used four nuclear loci (both rRNA and protein coding genes) that have previously proved useful for the molecular investigation of taxa belonging to the genus Penicillium at various evolutionary levels. The internal transcribed spacer region (ITS1-5.8S-ITS2), domains D1 and D2 of the 28S rDNA, a region of the tubulin beta chain gene (benA) and part of the calmodulin gene $(\mathrm{cmd})$ were amplified by PCR and sequenced. Analysis of the rRNA genes and of the benA and $c m d$ sequence data indicates the presence of three isogenic isolates belonging to a genetically distinct species of the genus Penicillium, here described and named Penicillium simile sp. nov. (ATCC MYA-4591 ${ }^{\top}=$ CBS $129191^{\top}$ ). This novel species is phylogenetically different from $P$. raistrickii and other related species of the genus Penicillium (e.g. Penicillium scabrosum), from which it can be distinguished on the basis of morphological trait analysis.
\end{abstract}

\section{INTRODUCTION}

In recent years, the accurate and rapid detection of microfungal species present in the air of indoor workplaces has received a remarkable amount of attention due to the spread of diseases (e.g. allergic responses) caused by airborne moulds and yeasts (Keswani et al., 2005). The recognition and characterization of microfungal species is increasingly being performed by means of a molecular approach based on DNA sequencing analysis, as opposed to methods based exclusively on the observation of morphological traits, which yield poorer results (Taylor et al., 2000; Haugland et al., 2004; Davolos \& Pietrangeli, 2007).

Taxa belonging to the genus Penicillium have frequently been isolated from bioaerosols. However, although the toxin profiles and allergic reactions of these filamentous fungi differ considerably, they have rarely been identified at the species level (Ramírez et al., 1980). In this study, three

\footnotetext{
Abbreviations: ITS, internal transcribed spacer region; NJ, neighbourjoining; MP, maximum-parsimony.

A supplementary table and two supplementary figures are available with the online version of this paper.
}

phenetically identical Penicillium isolates, collected recently during a project conducted to investigate the bioaerosol in a restoration laboratory in Italy, which morphologically resemble Penicillium raistrickii but can be distinguished from the latter on the basis of macro- and microscopic characteristics, were subjected to a phylogenetic investigation to obtain a better taxonomic resolution and to gather information on their evolutionary relationships. As molecular markers related to the rRNA genes, we used the internal transcribed spacers (ITS1, ITS2) including the 5.8S rDNA gene, and the domains D1 and D2 of the 28S rDNA gene, together known as the ID region. In addition, two protein coding genes, the tubulin beta chain gene (benA) and the calmodulin gene $(\mathrm{cmd})$, were examined because they have previously proved to be useful for the molecular investigation of taxa belonging to the genus Penicillium at different taxonomic levels (e.g. Samson et al., 2004; Wang \& Zhuang, 2007; Serra et al., 2008).

The main goal of our study was to assess the taxonomic status and the phylogenetic position of these three peculiar Penicillium isolates by comparing their micro- and macromorphological characteristics and their nucleotide sequence divergence levels (using a multilocus approach) 
with those of other known species belonging to the genus Penicillium.

\section{METHODS}

Strains. $P$. simile sp. nov. strains $414^{\mathrm{T}}, 415$ and 416 were isolated from the air in three different places in a cultural heritage restoration laboratory at Castel Gandolfo (Rome, Italy) in May 2006. P. raistrickii $\mathrm{G}$ Smith strains $\mathrm{A} 2 \mathrm{a}-8$ and $3 \mathrm{Ba}-\mathrm{AP}-1$ were isolated from the bioaerosol in the crypt of the Capuchin friars in Rome (Italy) in May 2007. All microfungal strains were isolated using a volumetric air sampling surface air sampler, with $5.5 \mathrm{~cm}$ RODAC plates containing Sabouraud dextrose agar plus chloramphenicol.

Media and growth conditions. According to standardized descriptions, the isolates were examined phenotypically then cultured in Czapek yeast extract (CYA), Blakeslee's malt extract (MEA) and G25N agar in $9 \mathrm{~cm}$ polystyrene Petri dishes and incubated at 25, 5 and $37{ }^{\circ} \mathrm{C}$ for 7 days in the dark, as described by Pitt (1979). The capitalized colour names and codes used to describe the colony colours refer to Kornerup \& Wanscher (1967).

Micromorphological features. Micromorphological structures (conidia, phialides, metulae and stipes) were photographed and measured using a Leica DM 5000B digital microscope equipped with a Leica DFC420 C camera, differential interference contrast (DIC; also known as Nomarski optics) and Leica LAS image analysis software.

DNA extraction, PCR amplification and DNA sequencing. Samples of pure cultures from 3-day-old CYA agar plates were added to $1.5 \mathrm{ml}$ tubes containing TE buffer $[10 \mathrm{mM}$ Tris/ $\mathrm{HCl}(\mathrm{pH} 8.0)$, $1 \mathrm{mM}$ EDTA ( $\mathrm{pH} 4.5$ )], gently homogenized and then lysed by either sonication or enzymic digestion. For physical disruption, tubes were placed in a sonicator (ultrasonic bath LBS2; Falc Instruments) at 60 $\mathrm{KHz}$ for 3-5 min then heated at $100{ }^{\circ} \mathrm{C}$ for $5-10 \mathrm{~min}$. Samples were centrifuged in a micro-centrifuge for $2 \mathrm{~min}$ at 14000 r.p.m. at room temperature, and the supernatant extracts containing unpurified fungal DNA were then stored at $-20{ }^{\circ} \mathrm{C}$ for subsequent PCR analysis. Enzymic digestion was instead initially performed with lyticase (20 mg ml${ }^{-1}$; Sigma) at $40{ }^{\circ} \mathrm{C}$ for $1 \mathrm{~h}$, and then by incubating with proteinase $\mathrm{K}\left(20 \mathrm{mg} \mathrm{ml}{ }^{-1}\right.$; Sigma) at $50-60{ }^{\circ} \mathrm{C}$ for several hours followed by phenol/chloroform extraction and alcohol precipitation to yield PCR-amplifiable genomic DNA; the resulting DNA pellets were dissolved in 50-100 $\mu \mathrm{l} \mathrm{TE}$ buffer and stored at $-20{ }^{\circ} \mathrm{C}$.

For the $5.8 \mathrm{~S}$ rDNA, ITS1, ITS2 and the D1 and D2 regions of the $28 \mathrm{~S}$ rDNA gene, together known as the ID region, approximately 1100 base pairs (bp), PCR was performed by using primers ITS1, ITS4 (White et al., 1990) and NL-4 (O'Donnell, 1993). In addition, a region of approximately 900 bp of the tubulin beta chain ( $\beta$-tubulin) gene (benA) was amplified by using primer benA1 (Geiser et al., 1998) and the new reverse primer benA3 (5'-GGAAGGGAACGATGTTGAC-3'; Davolos \& Pietrangeli, 2007) based on conserved regions of the fungal $\beta$-tubulin gene sequence available from GenBank (NCBI). The region of the $\beta$-tubulin monomer examined encodes the $\mathrm{N}$ terminal domain [that includes the first 205 residues in which parallel $\beta$-strands (B) alternate with $\alpha$-helices $(\mathrm{H})]$ and helices $\mathrm{H} 6$ and $\mathrm{H} 7$ (residues 206-240) of the intermediate domain (Nogales et al., 1998). Furthermore, a 550-600 bp-long region of the calmodulin gene $(\mathrm{cmd})$, flanking parts of the second and fifth exons, was amplified and sequenced using the primers $\mathrm{cmd}-\mathrm{f}$ [ $5^{\prime}$-GATTCCCTCACCGAAGAGCA-3'; present study, a modification of the cmdD3 primer (Wang \& Zhuang, 2007) based on the cmd sequence from the genome of Penicillium chrysogenum Wisconsin 54-1255 (van den Berg et al., 2008; Supplementary Table S1, available in IJSEM Online] and cmdA1 (5'-GCCTCACGGATCATCTCGTC-3'; Wang \& Zhuang, 2007), and for $P$. simile sp. nov., the new primers $\mathrm{cmd} 2-\mathrm{f}$ ( $5^{\prime}$-AGTGTCGGAGTACAAGGAGGC-3'; present study) and cmd-r (5'-ATCTCGTCCACCTCGTCGTC- $3^{\prime}$; present study) designed according to the $\mathrm{cmd}$ gene sequences of $P$. scabrosum strains available from GenBank (Supplementary Table S1) and of strains A2a-8 and 3Ba-AP-1 of $P$. raistrickii newly sequenced in this study (Supplementary Table S1).

PCR amplification was performed using Taq DNA polymerase with aliquots of each cell lysate suspension or genomic DNA in TE buffer as a template. Conditions for PCR amplification were: 2 min at $95{ }^{\circ} \mathrm{C}$, followed by 35 cycles, each consisting of $95{ }^{\circ} \mathrm{C}$ for 40 s, $50-52{ }^{\circ} \mathrm{C}$ for 40s, and 1-3 min (according to the examined region size) at $72{ }^{\circ} \mathrm{C}$. The final PCR extension step was $10 \mathrm{~min}$ at $72{ }^{\circ} \mathrm{C}$. PCR products were analysed on a $1 \%$ agarose gel and visualized with specific dyes for DNA. Purified PCR products were sequenced (using BigDye terminator v3.1; Applied Biosystems) on both strands using the same PCR primers. Cycle-sequencing reactions were sequenced on an Applied Biosystems ABI Prism 3100 DNA Sequencer.

Gene sequence and phylogenetic analysis. Nucleotides and inferred amino acid residues were compared with accessible data from GenBank databases using NCBI's BLAST server. Sequence alignments were performed by using the CLUSTAL X v.1.8 program. Phylogenetic analyses were conducted by using the neighbour-joining (NJ) method, and the maximum-parsimony (MP) method with unweighted codon positions and the close-neighbour-interchange option. The substitution model for the nucleotide sequences was the Kimura twoparameter with complete deletion of gaps; both transitions and transversions were included in the analysis. Phylogenetic analyses performed by means of the NJ and MP methods were conducted using MEGA 4 (Tamura et al., 2007) calculating 1000 bootstrap replicates. As the 28S rRNA and $c m d$ genes for some of the species examined were not available from GenBank (Supplementary Table S1), concordance was evaluated only for the ITS1-5.8S-ITS2 (known as the ITS region) and the tubulin beta chain gene datasets with the partition homogeneity test implemented with PAUP $^{\star} 4.0 \mathrm{~b} 10$, using 1000 replicates and the heuristic general search option (Swofford, 2003). The partition homogeneity test revealed no significant difference between the ITS region and the tubulin beta chain gene $(P=0.62)$; we also performed a phylogenetic analysis by pooling the ITS and benA sequences.

Bayesian analyses were performed in MrBayes v.3 (Ronquist \& Huelsenbeck, 2003). The number of substitution types was set to six, and the evolutionary model to the generalized time-reversible model with a gamma-distributed rate variation across sites and a proportion of invariable sites $(\mathrm{GTR}+\mathrm{Gamma}+\mathrm{I})$; all priors were left default to allow estimation of the parameters from the data. Two independent Markov chain Monte Carlo analyses were run simultaneously for $5 \times 10^{6}$ generations and sampled every 100 generations. The first $25 \%$ of the generations were discarded as burn-in and a $50 \%$ majority rule consensus tree was calculated from the remaining trees.

Sequences of the ID region and the ben $A$ and $c m d$ genes from $P$. simile sp. nov. and $P$. raistrickii obtained in the present study were deposited in the NCBI database (Supplementary Table S1). In addition, since some species of the genus Penicillium, including $P$. raistrickii, were traditionally classified in the subgenus Furcatum but can be inserted within the subgenus Penicillium (Peterson, 2000; Peterson et al., 2003; Frisvad et al., 2006), the ITS1-5.8S-ITS2, 28S rDNA, and benA and $c m$ gene sequences obtained from single Penicillium lineages phylogenetically representing both the subgenus Furcatum (Penicillium citrinum and Penicillium decaturense; Supplementary Table S1) and the subgenus Penicillium (Penicillium brevicompactum, P. chrysogenum strains G6 and Wisconsin 54-1255, and Penicillium olsonii; Supplementary Table S1) were included in the phylogenetic analysis and used for the multiple gene comparison. 


\section{RESULTS}

\section{Morphology}

The Penicillium strains $414^{\mathrm{T}}, 415$ and 416 displayed identical colony and microscopic morphologies. On the basis of their micro- and macromorphological features, these three Penicillium isolates appeared to be most closely related to $P$. raistrickii $\mathrm{G}$. Smith. The similarities we observed included: a velvety, or nearly velvety, colony surface on CYA that was radiately sulcate, with white floccose aerial hyphae; roughened conidiophore walls; the presence of bi- and terverticillate penicilli; spheroidal conidia with smooth, or nearly smooth, walls; well-developed globose to subglobose sclerotia. Other morphological characteristics were, however, distinguishable. The most noticeable differences between these three Penicillium isolates and $P$. raistrickii were: on CYA, a colony surface that was radiately sulcate with few furrows and reversed colouring (from light yellow to brown); the presence of light brown exudates; on MEA, the presence of the centre overlaid with sectors of shallow radiating white sterile hyphae; penicilli that were often terverticillate, yielding conidiophores that were less rugose with shorter stipes, metulae and phialides and with bigger conidia.

Penicillium strains $414^{\mathrm{T}}, 415$ and 416 also shared some morphological similarities with $P$. scabrosum (Frisvad et al., 1990), including a velutinous texture and white and/or yellow mycelium on CYA and occasionally redbrown exudates; however, our three isolates differed from $P$. scabrosum in the following ways: slower mycelial growth rate both on CYA $\left(26-32 \mathrm{~mm}\right.$ diam. after 1 week at $\left.25^{\circ} \mathrm{C}\right)$ and on MEA (21-31 mm diam. after 1 week at $25^{\circ} \mathrm{C}$ ), colony reverse strongly coloured red-brown in conspicuous concentric zones, colour often diffusing into the agar even on MEA; noticeably roughened and often encrusted conidiophores, ramus at an angle of approx. $45^{\circ}$, much longer metulae and phialides, rough-walled conidia and absence of sclerotia.

The micro- and macromorphological differences observed in Penicillium strains $414^{\mathrm{T}}, 415$ and 416 in comparison with $P$. raistrickii, $P$. scabrosum and other related species, e.g. Penicillium soppii, belonging to Section Ramosum, series Lanosa (Stolk \& Samson, 1985; see Frisvad et al., 2006), suggested that they should be transferred to Penicillium simile sp. nov., a novel species described here (Figs 1 and 2).

\section{Molecular and phylogenetic analysis}

For the P. simile sp. nov. strains $414^{\mathrm{T}}$ (holotype, see below), 415 and 416, and for the P. raistrickii strains A2a-8 and $3 \mathrm{Ba}-\mathrm{AP}-1$, the primers for the rRNA regions successfully amplified PCR products of the expected size, a total of approximately $1100 \mathrm{nt}$ (Supplementary Table S1). The sequences obtained from the ID region were aligned with sequences extracted from GenBank (NCBI). P. simile $414^{\mathrm{T}}$ (holotype) and the two additional isolates (415 and 416)

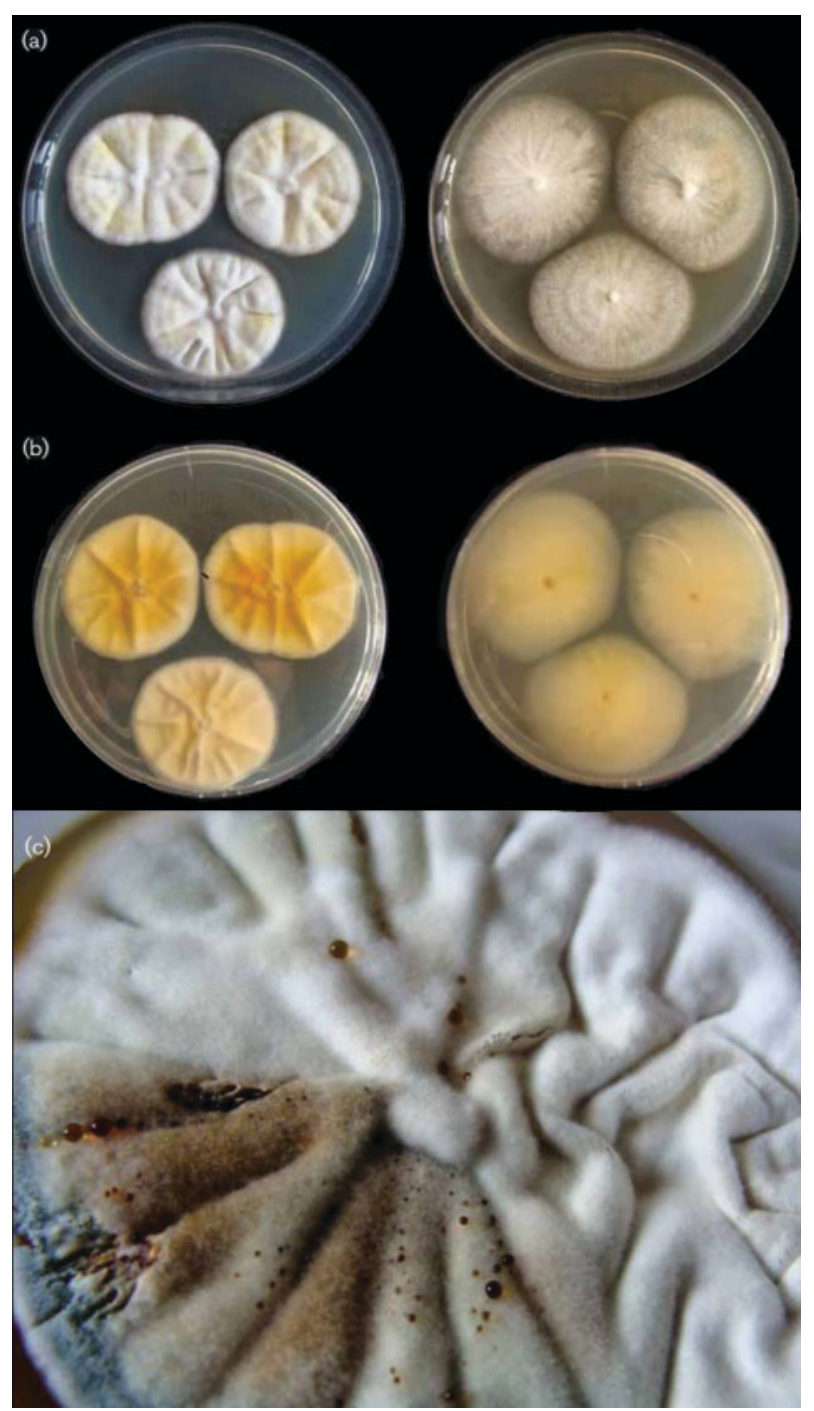

Fig. 1. Colonies of strain ATCC MYA-4591 ${ }^{\top}$ : $(a, b)$ grown on CYA (left) and MEA (right) at $25{ }^{\circ} \mathrm{C}$, after 7 days, front (a) and reverse (b) views; (c) colony showing radial sulcation and brown exudates.

appeared invariant in the ID region sequences examined. The ITS1-5.8S-ITS2 sequences (approx. $535 \mathrm{nt}$ ) of $P$. simile were similar to those of the $P$. raistrickii strains deposited in the NCBI database (Supplementary Table S1), exhibiting three different nucleotides in ITS1 (a transversion, $\mathrm{C} \rightarrow \mathrm{A}$ ) and ITS2 (two transversions, $\mathrm{T} \rightarrow \mathrm{A}$ and $\mathrm{A} \rightarrow \mathrm{T}$ ). BLAST analysis of the examined $615 \mathrm{nt}$ region of the 28S rDNA gene of $P$. simile compared with those available for $P$. raistrickii (Supplementary Table S1) revealed only a transition $(\mathrm{G} \longrightarrow \mathrm{A})$ yielding a $99.8 \%$ identity. A marked identity emerged in comparison with Penicillium swiecickii NRRL $918^{\mathrm{T}}$ (Supplementary Table S1) and $P$. soppii NRRL $2023^{\mathrm{T}}$ (=IBT $18220^{\mathrm{T}}$; Frisvad et al., 2006; GenBank no. AF033488), 99.3 and $99 \%$, respectively. The ITS1-5.8S-ITS2 and 28S rDNA trees (data not shown) 

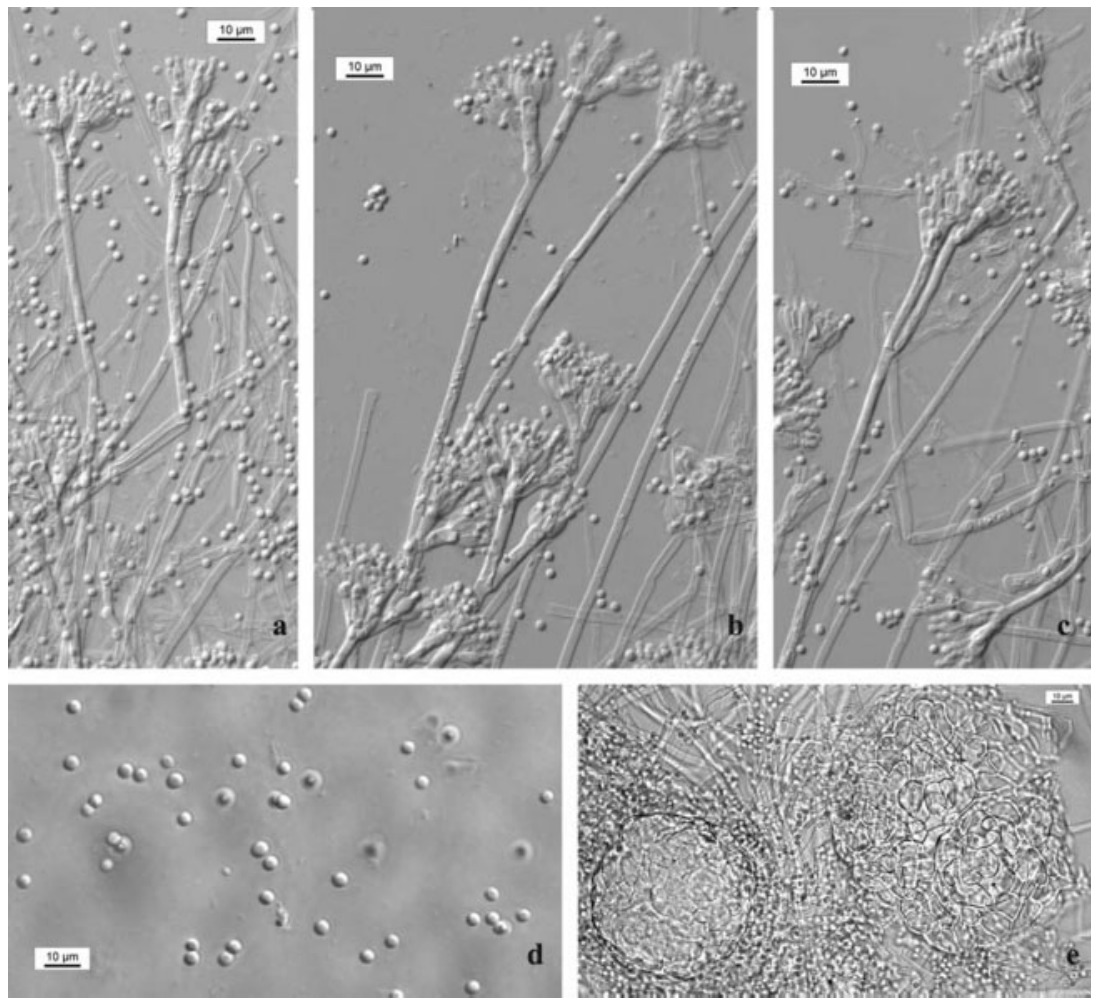

Fig. 2. Strain ATCC MYA-4591': (a-c) conidiophores, (d) conidia, (e) sclerotia; (a-d) Nomarski interference contrast light microscopy. Bars, $10 \mu \mathrm{m}$. demonstrated the presence of two main clades: one group corresponded to species belonging to the subgenus Furcatum ( $P$. citrinum and $P$. decaturense; Supplementary Table S1), while the other clade was formed by all the remaining species examined, including those chosen here to represent the subgenus Penicillium (e.g. P. brevicompactum and $P$. olsonii; Supplementary Table S1); within the latter partition, $P$. simile sp. nov. was most closely related to $P$. raistrickii.

Furthermore, for the $P$. simile sp. nov. strains $414^{\mathrm{T}}$ (holotype), 415 and 416, and for $P$. raistrickii A2a-8 and 3Ba-AP-1 (Supplementary Table S1), a section (approx. $900 \mathrm{bp}$ ) of the benA gene was amplified and sequenced by the primers benA1 and benA3. An exon-intron structure, assigned by comparing DNA sequences with homologous sequences extracted from GenBank (NCBI), indicated that the introns were bounded by canonical GT-AG splice sites. From the partial benA sequence analysis, $P$. simile $414^{\mathrm{T}}$ (holotype) and the two isolates 415 and 416 appeared isogenic. $P$. simile and $P$. raistrickii $\mathrm{A} 2 \mathrm{a}-8$ and $3 \mathrm{Ba}-\mathrm{AP}-1$ had the same intron size, though a single deletion was observed in the former. A certain degree of divergence emerged in the benA gene sequences (four-eight base pair differences) of previously studied strains (including IBT $21396^{\mathrm{T}}$ ) of $P$. raistrickii. $P$. raistrickii A2a-8 and $3 \mathrm{Ba}-\mathrm{AP}-1$ displayed identical benA gene sequences and, when compared with other strains of $P$. raistrickii, yielded a 98$100 \%$ nucleotide identity (the nucleotide changes occurred in the non-coding regions alone). The benA sequence divergence value between $P$. simile and $P$. raistrickii was approximately $3.4 \%$; the divergence was mainly located in the regions of introns, while their exon sequences only yielded eight different nucleotides. The nucleotide changes in the protein coding region occurred mainly as silent changes, though a single non-synonymous transition (GUU for valine $\rightarrow$ AUC for isoleucine in $\alpha$-helix H5) was found in $P$. raistrickii (strains $\mathrm{BLSA} 11 \mathrm{t}, \mathrm{A} 2 \mathrm{a}-8$ and $3 \mathrm{Ba}-\mathrm{AP}-1$, for which a comparable $900 \mathrm{nt}$ sequence length has been obtained; Supplementary Table S1).

Phylogenetic analysis conducted using the NJ and MP methods revealed the same tree topology. The NJ cladogram of the partial $\beta$-tubulin gene produced by using bootstrap analysis in Fig. 3 shows that the species of the genus Penicillium examined generally resolved into well supported clades. A clear separation emerged for the clade formed by the two species belonging to the subgenus Furcatum (Supplementary Table S1). The $P$. raistrickii strains A2a-8 and $3 \mathrm{Ba}-\mathrm{AP}-1$ clustered together in a clade that formed with other conspecific taxa (Fig. 3). P. simile sp. nov. was most closely related to $P$. raistrickii, but was clearly distinct from the latter species (bootstrap value of $99 \%$; Fig. 3). $P$. scabrosum appeared to be a sister species (bootstrap value of $51 \%$ ) in relation to the clade formed by $P$. simile and $P$. raistrickii (Fig. 3). Bayesian analysis of the benA gene sequences (data not shown) generally confirmed the results yielded by the NJ phylogenetic analysis (Fig. 3), including the observation that $P$. simile and $P$. raistrickii were two distinct evolutionary entities (1.00 posterior probability) and that $P$. scabrosum was recognized as their basal lineage (posterior probability of 0.94 ). 


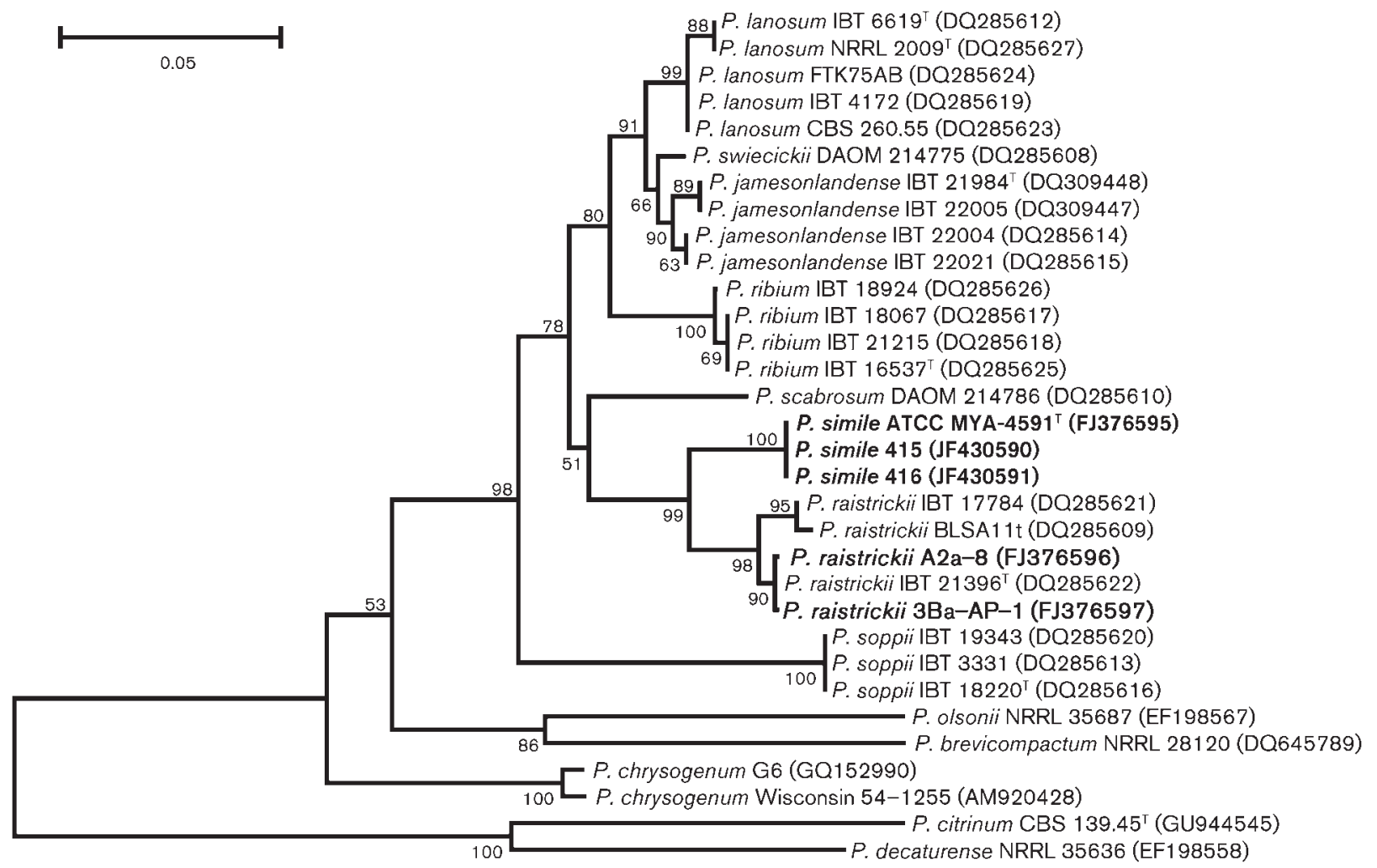

Fig. 3. Neighbour-joining tree of $P$. simile sp. nov. and other taxa of the genus Penicillium examined based on ben $A$ gene sequence data (GenBank accession numbers are shown in parentheses; sequences obtained in the present study are highlighted in bold). Numbers near branches are bootstrap values (1000 pseudoreplicates). Bar, 0.05 substitutions per nucleotide position.

The NJ tree of the combined sequences of the ITS region and benA gene yielded the topology shown in Supplementary Fig. S1. P. simile sp. nov. and P. raistrickii were well separated (bootstrap value of $97 \%$; Supplementary Fig. S1). $P$. scabrosum emerged as a sister species (bootstrap value of $94 \%)$ to the clade formed by $P$. simile and $P$. raistrickii as well as to another clade (89\%) including Penicillium lanosum, P. swiecickii, Penicillium jamesonlandense and Penicillium ribium (Supplementary Fig. S1).

In addition, cmd gene sequences (approx. $600 \mathrm{bp)} \mathrm{were}$ obtained for $P$. simile sp. nov. (holotype; Supplementary Table S1) and for the $P$. raistrickii strains $\mathrm{A} 2 \mathrm{a}-8$ and $3 \mathrm{Ba}-$ AP-1 (Supplementary Table S1). The introns were bounded by GT-AG splice sites; the two isolates of $P$. raistrickii yielded identical $\mathrm{cmd}$ sequences. A BLAST analysis showed that the $c m d$ gene sequences of $P$. simile displayed $86 \%$ sequence similarity with the $\mathrm{cm}$ d gene from strains of $P$. scabrosum. In the cmd region we examined, $P$. simile displayed unique $\mathrm{cmd}$ gene sequences that distinguished it from $P$. raistrickii. In particular, the $P$. simile and $P$. raistrickii strains (Supplementary Table S1) had different nucleotides (sequence divergence value of approx. 6.5\%) in the intron regions (the third and the fourth intron were slightly different in length due to the presence of indels) while their exon sequences were nearly identical, exhibiting seven different nucleotides that occurred as synonymous changes. Three transitions that occurred in $P$. raistrickii appeared to be apomorphic substitutions in relation to the $\mathrm{cmd}$ gene sequences of $P$. simile and $P$. scabrosum. The topology of the NJ tree yielded by the $c m d$ sequences (Supplementary Fig. S2) also identified $P$. simile and $P$. raistrickii as two clearly separate species (100\% bootstrap support); P. scabrosum emerged as the basal taxon (bootstrap support of $93 \%$ ) to the clade formed by these two species (Supplementary Fig. S2). The Bayesian inference on the $\mathrm{cmd}$ sequences (data not shown) complemented the information yielded by the NJ phylogenetic analyses (Supplementary Fig. S2) and confirmed the genetic separation between $P$. simile and $P$. raistrickii (1.00 posterior probability).

\section{DISCUSSION}

The increasing amount of attention being dedicated to microfungal species in indoor environments in recent years has enhanced the need for detailed investigations of airborne moulds and yeasts. In particular, a thorough knowledge of airborne microfungal diversity sheds light on the role such microfungi play in respiratory problems, such 
as allergies (Scott et al., 2004; Davolos \& Pietrangeli, 2007). In this regard, the analysis of gene sequences has proved to be an important means of understanding evolutionary relationships at different taxonomic levels for genera such as Penicillium, whose identification on the basis of morphological features has recently posed a challenge (Peterson, 2004; Peterson et al., 2004; Samson et al., 2004). Molecular data have already indicated the genetic isolation of several taxa in the genus Penicillium, thereby allowing recent evolutionary speciation among morphologically closely related species to be evaluated (Samson et al., 2004; Kwaśna \& Nirenberg, 2005; Serra \& Peterson, 2007; Sonjak et al., 2007a, b) and geographically restricted taxa to be identified (Scott et al., 2004).

In the present study, the two isolates $\mathrm{A} 2 \mathrm{a}-8$ and $3 \mathrm{Ba}-\mathrm{AP}-1$, which were isogenic at each of the loci examined, displayed identical ID region sequences and very similar benA gene sequences (98.5-100\% identity) to those of $P$. raistrickii deposited in GenBank (at the time of writing, $\mathrm{cmd}$ sequences for $P$. raistrickii were not available in public databases, thus preventing a phylogenetic comparison using this gene), and are identified as such (Supplementary Table S1; Fig. 3; Supplementary Fig. S1); future studies are warranted to determine whether they are biogeographically rare or widespread strains. It is noteworthy, however, that the strains of $P$. raistrickii displayed a certain degree of morphological variability, which points to infraspecific genetic variation (Fig. 3). Future taxonomic studies are needed to redefine the specific structures of this species on the basis of all the information available on taxa belonging to the species.

Although the features of $P$. simile sp. nov., the novel species of the genus Penicillium being proposed here, appear to be highly similar to those of $P$. raistrickii, these two species are morphologically distinguishable. Indeed, the differences between $P$. simile (Figs 1 and 2 ) and $P$. raistrickii can easily be observed by means of both macromorphological (mycelia, hyphae, exudates) and micromorphological (penicilli, metulae, phialides and conidia) investigation.

As regards the molecular data we obtained, the P. simile sp. nov. isolates were isogenic at the loci examined, as might be expected given that all three were collected from the same locality. Although the ID region sequences of $P$. simile are similar to those of $P$. raistrickii (Supplementary Table S1), $P$. simile is clearly distinct, as the statistical results unequivocally indicate, from $P$. raistrickii in both the $\beta$-tubulin and calmodulin gene regions analysed (Fig. 3, Supplementary Figs S1 and S2), which confirms the phylogenetic importance of such protein coding genes in the study of closely related species of the genus Penicillium.

Indeed, the phylogenetic position of $P$. simile sp. nov. is distinct within a strongly supported clade based on benA gene sequences of $P$. jamesonlandense, $P$. lanosum, $P$. raistrickii, $P$. ribium, $P$. scabrosum, $P$. soppii and $P$. swiecickii (Fig. 3), which are traditionally classified in the subgenus Furcatum but can, according to recent molecular studies (see Peterson, 2000; Peterson et al., 2003; Frisvad et al.,
2006), be inserted within the subgenus Penicillium. Our results are in agreement with those of recent studies in which the $\beta$-tubulin gene sequences were found to be more variable than those of the ITS region and other genes, often allowing closely related Penicillium lineages to be discriminated (Seifert et al., 2007; Peterson \& Horn, 2009; Houbraken et al., 2010, 2011). Indeed, the $\beta$-tubulin gene divergence value found between $P$. simile and $P$. raistrickii (approx. 3.4\%) can be ascribed to the range of genetic variation data between species of the genus Penicillium (0.5$67.2 \%)$ previously obtained from homologous sequences (Samson et al., 2004; Seifert et al., 2007; O'brien et al., 2008; Houbraken et al., 2010, 2011). Intriguingly, the substitution of the highly conserved valine residue for isoleucine (both non-polar amino acids) in $\alpha$-helix H5 (see Nogales et al., 1998 ) found in $P$. raistrickii may be considered an apomorphic molecular trait if compared with related species including P. simile (Fig. 3).

In addition, in the $\mathrm{cmd}$ gene region examined, $P$. simile sp. nov. and $P$. raistrickii appear as two distinct species, as the statistical data clearly indicate (Supplementary Fig. S2); their cmd gene sequence similarity is $92.3 \%$, a value that is lower than those reported for closely related species of the genus Penicillium (Wang \& Zhuang, 2007; Peterson \& Horn, 2009). Moreover, some transitions found in the $\mathrm{cmd}$ regions of $P$. raistrickii appear to be apomorphic substitutions, while $P$. simile, $P$. scabrosum and other related species of the genus Penicillium retained the plesiomorphic sequences of the gene.

At present, the information available for the two protein coding loci we examined in this study indicates that $P$. scabrosum may be representative of an early evolutionary stage of $P$. simile sp. nov. and $P$. raistrickii (Fig. 3, Supplementary Fig. S2), thereby suggesting that these three species of the genus Penicillium share a common ancestor. The analysis based on the ITS sequences alone reveals few phylogenetically informative sites due to the low variability of this rRNA region (including the identical 5.8S rDNA gene sequences) at that evolutionary scale (see Frisvad et al., 2006). However, the very high bootstrap proportions and Bayesian posterior probabilities suggest, even when the ITS and benA gene sequences are pooled (Supplementary Fig. S1), that $P$. simile has an independent evolutionary lineage.

To sum up, our molecular data suggest that $P$. simile sp. nov. and $P$. raistrickii have evolved, as the morphological differences between these species suggest, and should be treated as two closely related, though distinct entities (Fig. 3, Supplementary Figs S1 and S2). These two species of the genus Penicillium are likely to have evolved recently from a common ancestor as suggested by low genetic divergence values. In particular, analyses of the $\beta$-tubulin and calmodulin gene coding regions (similar exon sequences) point to a recent speciation event within this monophyletic group (Fig. 3, Supplementary Figs S1 and S2), in which $P$. raistrickii appears to exhibit derived molecular traits. 


\section{Taxonomy}

\section{Latin diagnosis of Penicillium simile Davolos, Pietrangeli, Persiani \& Maggi sp. nov.}

Coloniae in agaro CYA crescentes, post 7 dies $25{ }^{\circ} \mathrm{C}, 35 \mathrm{~mm}$ diam, radialiter sulcatae et centraliter umbonatae, textura superficiei velutinosa ad moderate floccose, margines regulares, moderate profundae, mycelium album ad pallens (M. 1-2A3) usque ad moderate brunneum (M. 5D6-8); conidiogenesis diffusa quondam moderata, concolor callaidis (M. 24A-B6); sclerotia mycelio circumdata, alba ad pallentia (M. 3A3); exudatum moderate brunneum adest (M. 6D1-2); pigmentum dissolubile abest, facies reversa flavam ad brunneam (M. 7DE7). Coloniae in agaro MEA crescentes, post 7 dies $25^{\circ} \mathrm{C}$, $45 \mathrm{~mm}$ diam, plane, radialiter hyphae albae crescentes; sclerotia adsunt post 14 dies, alba ad flavida (M. 3A6-7); exudatum abest, conidiogenesis griseo-viridis (M. 25C4) ad profunde viridem (M. 25E4); facies reversa pallens ad luteam (M. 4A-B8). In agaro $\mathrm{G} 25 \mathrm{~N}$ coloniae $13-15 \mathrm{~mm}$ diam, plane ad radialiter sulcatae, conidiogenesis moderata, facies reversa pallens. Incubata ad $5{ }^{\circ} \mathrm{C}$ post 7 dies coloniae $3-5 \mathrm{~mm}$ diam, mycelium album. Incubata ad $37^{\circ} \mathrm{C}$ in CYA incrementum nullum post 7 dies. Conidiophora portata in aereis et sub superficie orientibus hyphis, stipes fere longus et latus 280$380 \times 3.8-4.7 \mu \mathrm{m}$, rugosa, portantes penicillos biverticillatos et terverticillatos, rami rugosi, $20-23 \times 2.8-3.8 \mu \mathrm{m}$; metulae 3-5 verticillatae, $9.5-11.5 \times 2.8-3.8 \mu \mathrm{m}$, in apice inflatae vel clavatae, 5.7-6 $\mu \mathrm{m}$, aliquando rugosae; phialides 8-10 verticillatae, ampulliformes, $6.6-7 \times 3.5-3.8 \mu \mathrm{m}$; conidia globosa, 2.3-3.3 $\mu \mathrm{m}$, levia, portata in catenis divaricatis. Sclerotia 130 $260 \mu \mathrm{m}$ diam; Status teleomorphosis ignotus. Typus $414^{\mathrm{T}}$. MB509645.

\section{Description of Penicillium simile Davolos, Pietrangeli, Persiani \& Maggi sp. nov. (Figs 1 and 2)}

Colonies grown for 7 days on CYA at $25^{\circ} \mathrm{C}$ attain $35 \mathrm{~mm}$ diameter, are deeply radially sulcate, centrally umbonate, with a velutinose to moderately floccose texture; moderately deep to deep margins, which are entire (Fig. 1a, left); usually white to pale yellow (M. 1-2A3) or light brown (M. 5D6-8) mycelium; conidiogenesis is often sparse and confined to margin, sometimes moderate and coloured turquoise blue to greyish turquoise (M. 24A-B6); sclerotia usually enveloped by mycelium, white to pale yellow (M. 3A3) with sclerotioid texture (Fig. 2e); exudates usually present (Fig. 1c), light brown (M. 6D1-2); soluble pigment absent; reverse (Fig. 1b, left) from light yellow to brown (M. 7D-E7). Colonies grown for 7 days on MEA at $25{ }^{\circ} \mathrm{C}$ attain $45 \mathrm{~mm}$ diameter, are plane, not furrowed, with the centre overlaid in sectors by shallow radiate white sterile hyphae, obscuring the otherwise heavily sporing areas (Fig. 1a, right); strictly velutinous surface texture, margins subsurface, entire, white mycelium; sclerotia not visible after 7 days but visible after 14 days, white to yellow (M.
3A6-7); conidiogenesis moderate from greyish green ( $\mathrm{M}$. 25C4) to dull green (M. 25E4); exudates absent; soluble pigment absent; reverse pale in localized sectors corresponding to the overgrowth of vegetative hyphae (Fig. 1b, right), up to orange yellow (M. 4A-B8). On G25N medium, colonies attain $13-15 \mathrm{~mm}$ diameter, are plane or lightly radially sulcate, consisting of dense white mycelium with low to deep margins, which are entire; moderate conidiogenesis, absent exudates and soluble pigment; reverse pale. At $5{ }^{\circ} \mathrm{C}$, colonies usually attain 3-5 mm diameter composed of white mycelium. When incubated at $37^{\circ} \mathrm{C}$, no growth is observed in 7 days.

Conidiophores borne from subsurface mycelium as well as from aerial hyphae, with stipes usually $280-380 \times 3.8-$ $4.7 \mu \mathrm{m}$, occurring at marginal areas, thick and rugose wall, terminating in biverticillate and terverticillate penicilli (Fig. $2 \mathrm{a}, \mathrm{b}, \mathrm{c})$ with rough-walled rami, $20-23 \times 2.8-3.8 \mu \mathrm{m}$; terminal metulae in divergent verticils of $3-5$, apically inflated or clavate, to $5.7-6 \mu \mathrm{m}$ at the apices, measuring 9.5-11.5 $\times 2.8-3.8 \mu \mathrm{m}$, sometimes rough-walled; phialides in verticils of $8-10$ per metula, ampulliform, $6.6-7 \times 3.5-$ $3.8 \mu \mathrm{m}$; conidia spheroidal, $2.3-3.3 \mu \mathrm{m}$, smooth-walled (Fig. 2d), borne in divergent columns; sclerotia with diameter $130-260 \mu \mathrm{m}$ (Fig. 2e); not known to produce a teleomorphic state.

\section{Holotype}

Strain $414^{\mathrm{T}}$ has been deposited (as a herbarium specimen) in the Department of Environmental Biology, Sapienza University of Rome, Rome, Italy (two additional strains, designated 415 and 416, are located in the same herbarium), in the American Type Culture Collection (ATCC) with the accession number ATCC MYA-4591 ${ }^{\mathrm{T}}$, and in the Centraalbureau voor Schimmelcultures (CBS) Fungal Biodiversity Centre with the accession number CBS $129191^{\mathrm{T}}$. Mycobank accession no. MB509645.

\section{Etymology}

simile (L. neut. adj.) from the Latin word similis which means 'similar, related' and reflects the close morphological similarity of the novel species to $P$. raistrickii.

\section{ACKNOWLEDGEMENTS}

O. M. and A. M. P. are very grateful to Professor G. Tarsitani (Hygiene Institute, Sapienza University of Rome, Rome, Italy) and Dr G. Pasquariello (National Institute for Graphics, Rome, Italy) for offering us the opportunity to participate in their indoor air research in the laboratories of cultural heritage restoration.

\section{REFERENCES}

Davolos, D. \& Pietrangeli, B. (2007). DNA sequencing and phylogenetic analysis of allergen-encoding genes from airborne moulds and yeasts. Prev Oggi 3, 23-35. 
Frisvad, J. C., Samson, R. A. \& Stolk, A. C. (1990). A new species of Penicillium, P. scabrosum. Persoonia 14, 177-182.

Frisvad, J. C., Larsen, T. O., Dalsgaard, P. W., Seifert, K. A., LouisSeize, G., Lyhne, E. K., Jarvis, B. B., Fettinger, J. C. \& Overy, D. P. (2006). Four psychrotolerant species with high chemical diversity consistently producing cycloaspeptide A, Penicillium jamesonlandense sp. nov., Penicillium ribium sp. nov., Penicillium soppii and Penicillium lanosum. Int J Syst Evol Microbiol 56, 1427-1437.

Geiser, D. M., Frisvad, J. C. \& Taylor, J. W. (1998). Evolutionary relationships in Aspergillus section Fumigati inferred from partial $\beta$ tubulin and hydrophobin DNA sequences. Mycologia 90, 831-845.

Haugland, R. A., Varma, M., Wymer, L. J. \& Vesper, S. J. (2004). Quantitative PCR analysis of selected Aspergillus, Penicillium and Paecilomyces species. Syst Appl Microbiol 27, 198-210.

Houbraken, J., Frisvad, J. C. \& Samson, R. A. (2010). Taxonomy of Penicillium citrinum and related species. Fungal Divers 44, 117-133.

Houbraken, J., López Quintero, C. A., Frisvad, J. C., Boekhout, T., Theelen, B., Franco-Molano, A. E. \& Samson, R. A. (2011). Penicillium araracuarense sp. nov., Penicillium elleniae sp. nov., Penicillium penarojense sp. nov., Penicillium vanderhammenii sp. nov. and Penicillium wotroi sp. nov., isolated from leaf litter. Int J Syst Evol Microbiol 61, 1462-1475.

Keswani, J., Kashon, M. L. \& Chen, B. T. (2005). Evaluation of interference to conventional and real-time PCR for detection and quantification of fungi in dust. J Environ Monit 7, 311-318.

Kornerup, A. \& Wanscher, J. H. (1967). Methuen Handbook of Colour, 2nd edn. London: Methuen.

Kwaśna, H. \& Nirenberg, H. I. (2005). Delimitation of Penicillium virgatum sp. nov. and $P$. daleae on the basis of morphological and molecular characters. Mycol Res 109, 974-982.

Nogales, E., Wolf, S. G. \& Downing, K. H. (1998). Structure of the alpha beta tubulin dimer by electron crystallography. Nature 391, 199-203.

O'brien, M., Egan, D., O'kiely, P., Forristal, P. D., Doohan, F. M. \& Fuller, H. T. (2008). Morphological and molecular characterisation of Penicillium roqueforti and $P$. paneum isolated from baled grass silage. Mycol Res 112, 921-932.

O'Donnell, K. (1993). Fusarium and its near relatives. In The Fungal Holomorph: Mitotic, Meiotic and Pleomorphic Speciation in Fungal Systematics, pp. 225-233. Edited by D. R. Reynolds \& J. W. Taylor. Wallingford, UK: CAB International.

Peterson, S. W. (2000). Phylogenetic analysis of Penicillium species based on ITS and LSU-rDNA nucleotide sequences. In Integration of Modern Taxonomic Methods for Penicillium and Aspergillus Classification, pp. 163-178. Edited by R. A. Samson \& J. I. Pitt. Amsterdam: Harwood Academic.

Peterson, S. W. (2004). Multilocus DNA sequence analysis shows that Penicillium biourgeianum is a distinct species closely related to $P$. brevicompactum and P. olsonii. Mycol Res 108, 434-440.

Peterson, S. W. \& Horn, B. W. (2009). Penicillium parvulum and Penicillium georgiense, sp. nov., isolated from the conidial heads of Aspergillus species. Mycologia 101, 71-83.

Peterson, S. W., Pérez, J., Vega, F. E. \& Infante, F. (2003). Penicillium brocae, a new species associated with the coffee berry borer in Chiapas, Mexico. Mycologia 95, 141-147.

Peterson, S. W., Bayer, E. M. \& Wicklow, D. T. (2004). Penicillium thiersii, Penicillium angulare and Penicillium decaturense, new species isolated from wood-decay fungi in North America and their phylogenetic placement from multilocus DNA sequence analysis. Mycologia 96, 1280-1293.
Pitt, J. I. (1979). The Genus Penicillium and its Teleomorphic States Eupenicillium and Talaromyces. London: Academic Press.

Ramírez, C., Martinez, A. T. \& Berenguer, J. (1980). Four new species of Penicillium isolated from the air. Mycopathologia 72, 27-34.

Ronquist, F. \& Huelsenbeck, J. P. (2003). MrBayes 3: Bayesian phylogenetic inference under mixed models. Bioinformatics 19, 15721574.

Samson, R. A., Seifert, K. A., Kuijpers, A. F. A., Houbraken, J. A. M. P. \& Frisvad, J. C. (2004). Phylogenetic analysis of Penicillium subgenus Penicillium using partial $\beta$-tubulin sequences. Stud Mycol 49, 175200.

Scott, J., Untereiner, W. A., Wong, B., Straus, N. A. \& Malloch, D. (2004). Genotypic variation in Penicillium chysogenum from indoor environments. Mycologia 96, 1095-1105.

Seifert, K. A., Samson, R. A., Dewaard, J. R., Houbraken, J., Lévesque, C. A., Moncalvo, J. M., Louis-Seize, G. \& Hebert, P. D. (2007). Prospects for fungus identification using CO1 DNA barcodes, with Penicillium as a test case. Proc Natl Acad Sci U S A 104, 39013906.

Serra, R. \& Peterson, S. W. (2007). Penicillium astrolabium and Penicillium neocrassum, two new species isolated from grapes and their phylogenetic placement in the $P$. olsonii and P. brevicompactum clade. Mycologia 99, 78-87.

Serra, R., Peterson, S. W., CTCOR \& Venâncio, A. (2008). Multilocus sequence identification of Penicillium species in cork bark during plank preparation for the manufacture of stoppers. Res Microbiol 159, 178-186.

Sonjak, S., Ursic, V., Frisvad, J. C. \& Gunde-Cimerman, N. (2007a). Penicillium svalbardense, a new species from Arctic glacial ice. Antonie van Leeuwenhoek 92, 43-51.

Sonjak, S., Frisvad, J. C. \& Gunde-Cimerman, N. (2007b). Genetic variation among Penicillium crustosum isolates from arctic and other ecological niches. Microb Ecol 54, 298-305.

Stolk, A. C. \& Samson, R. A. (1985). A new taxonomic scheme for Penicillium anamorphs. In Advances in Penicillium and Aspergillus Systematics, pp. 163-190. Edited by R. A. Samson \& J. I. Pitt. New York: Plenum.

Swofford, D. L. (2003). PAUP*: Phylogenetic analysis using parsimony ( ${ }^{*}$ and other methods), version 4.0b10. Sunderland, MA: Sinauer Associates.

Tamura, K., Dudley, J., Nei, M. \& Kumar, S. (2007). MEGA4: molecular evolutionary genetics analysis (MEGA) software version 4.0. Mol Biol Evol 24, 1596-1599.

Taylor, J. W., Jacobson, D. J., Kroken, S., Kasuga, T., Geiser, D. M., Hibbett, D. S. \& Fisher, M. C. (2000). Phylogenetic species recognition and species concepts in fungi. Fungal Genet Biol 31, 21-32.

van den Berg, M. A., Albang, R., Albermann, K., Badger, J. H., Daran, J.-M., Driessen, A. J., Garcia-Estrada, C., Fedorova, N. D., Harris, D. M. \& other authors (2008). Genome sequencing and analysis of the filamentous fungus Penicillium chrysogenum. Nat Biotechnol 26, 11611168 .

Wang, L. \& Zhuang, W. Y. (2007). Phylogenetic analyses of penicillia based on partial calmodulin gene sequences. Biosystems 88, 113126.

White, T. J., Bruns, T., Lee, S. \& Taylor, J. (1990). Amplification and direct sequencing of fungal ribosomal RNA genes for phylogenetics. In PCR Protocols: a Guide to Methods and Applications, pp. 315-322. Edited by M. A. Innis, H. Gelfand, J. J. Sninsky \& T. J. White. New York: Academic Press. 